\title{
Environmental Flows in Nepal - An Evaluation of Current Practices and an Analysis of the Upper Trishuli-I Hydroelectric Project
}

\section{Narayanhari Rijal and Knut Alfredsen}

Abstract: Environmental assessments and environmental flows are important components in modern hydropower development. Various methods employing a combination of hydrology, hydraulics, environmental assessment and ecology have been developed for analysing and setting environmental flows. In the developed countries, detailed assessments are being carried out for setting environmental flows whereas very little attention has been given to this topic in Nepal. However, this trend is changing in recent developments. We discuss current minimum flow practices for a number of hydropower projects in the planning, development and operation phases to observe minimum flows and environmental flow over time. Furthermore, we present an analysis of environmental flows for the Upper Trishuli-I Hydroelectric Project in Nepal that is currently in the planning phase. We base our conclusion using current flow assessment methodologies to study the effects of proposed minimum flows and possible changes to improve the effect of compensatory releases.

Keywords: Environmental assessment, Environmental flows, Minimum flows, Flow assessment methodologies, Modelling, Nepal

\section{Introduction}

Jepal is rich in water resources, and the topography development. Harnessing hydropower could form a basis for overall prosperity for the nation. The sustainable use of water resources is a key issue for developing hydropower projects. The sustainability of these projects depends on the wise use of available natural resources with due consideration of the natural ecosystem. The common approach to protect an ecosystem is to maintain a minimum flow into the affected reaches; however, determining this flow is largely dependent on the approach used to define its volume. One of the most promising approaches for integrating human uses into the larger scope of ecological sustainability is the concept of Environmental Flows (EF), or the provision of water within rivers to conserve freshwater biodiversity (Dunbar et al., 2004). The main purpose of this study is to observe the current trends in defining environmental flows for future Nepalese hydropower systems by discussing the Upper Trishuli-I Hydroelectric Project (UT-I HEP) which is currently in the detailed design phase. We will compare the details of UT-1 HEP to EFs at other dams around the world.

$\mathrm{EF}$ is the flow required in the dewatered section of the river to protect and maintain the existing ecological condition of the river. Various methods have been defined for assessing environmental flow in water management projects based on the type of the project, its location and the governing regulations in the respective region of development. This variability in the assessment methodologies and the strategies used for application is of great interest to study the trend of Environmental Flow Assessments (EFAs) on global and regional scales (Rijal, 2014). In developed countries, various methods like Hydrological Index Method, Hydraulic Rating Methods, Habitat Simulation Methods and the Holistic Methods (Tharme, 2003) are widely used for environmental flow assessments. On the other hand, in developing countries like Nepal, simple hydrological indices based on the historical flow data have been used for environmental flow assessment.

\section{Environmental Flows in Nepal}

The history of hydropower development in Nepal goes back more than a century. However, less than one percent of its total hydropower potential has been developed. Therefore, there is a need of development of a number of hydropower projects in near future. In Nepal, seasonal variability of precipitation and runoff has resulted in the variation of the riverine ecosystems and, hence, the biodiversity. Therefore, there are obvious challenges in defining and implementing environmental flow regimes in water resources development in Nepal.

\section{Current Practices}

In Nepal, hydropower projects developed before 1992 did not have any mandatory requirements regarding the environmental protections. The introduction of the Water Resources Act in 1992 initiated a consideration of environmental protection during project development. The Water Resources Act, 1992 requires that "A person or a corporate body, who desires to conduct a survey or to utilize water resources, shall be required to submit an application to the prescribed officer or authority along with the economic, technical and environmental study report and with other prescribed particulars". The introduction of the Environment Protection Act (EPA), 1997 states the need for carrying out the Initial Environmental Examination (IEE) and Environmental Impact Assessment (EIA) for projects based on their installed capacity. The Environment Protection Rules (EPR, 1997) which is based on the EPA made it mandatory for projects above $50 \mathrm{MW}$ to conduct an EIA study and for those below 50 MW, an IEE study was required. However, the Hydropower Development Policy introduced in 2001 specifically mentions the amount of minimum flow that must be released. It states that "Downstream release shall be maintained, either $10 \%$ of minimum mean monthly discharge or the quantum 
identified in the EIA study whichever is higher" and "Implementation of Environmental Impact Assessment (EIA) recommendations shall be emphasized". Thus, all projects licensed after 2001 require a minimum flow criterion. This flow is derived using a traditional hydrological method which calculates a fixed percentage of the mean monthly flow or minimum mean monthly flow in the dewatered section of the river. This method does not account for the natural variability of flow in the river.

After the introduction of Hydropower Development Policy in 2001, there has been a rapid increase in the use of minimum flows to understand the impact of hydropower systems on the environment. This rise is depicted in Figure 1.

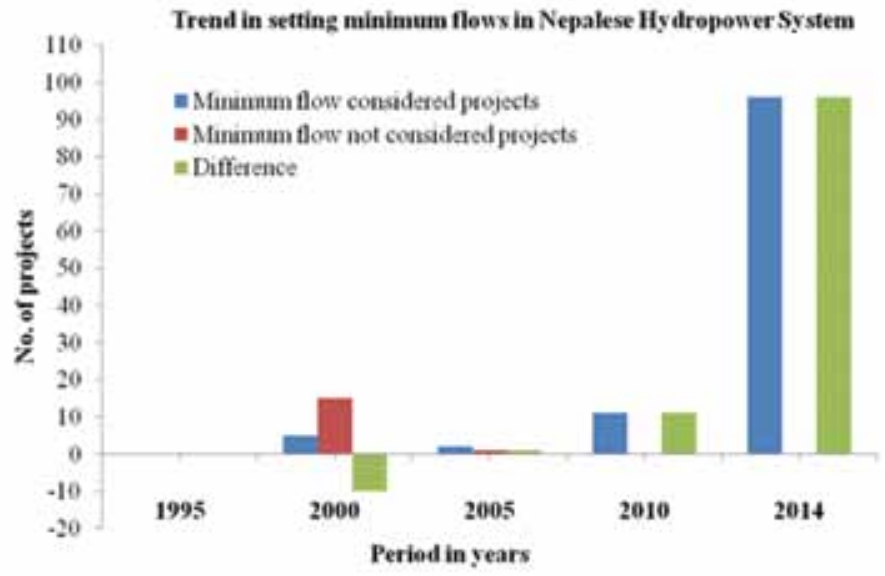

Figure 1: Trend of setting minimum flows in Nepalese Hydropower System

(Source: DoED)

The current practice in setting minimum flows is to apply the simple hydrological index method without paying attention to the ecological function of the released water in the dewatered section of the river. However, in recent developments, projects under planning and in the construction phase, especially those funded by donor agencies, have also started considering the environmental function of the minimum flow released downstream of the dam site. The EIA report of Upper Trishuli-I Hydroelectric Project proposes to release $10 \%$ of mean monthly flow as a minimum flow criterion. However, a detailed environmental flow study of the project supplemented by Cumulative Impact Assessment (CIA) is ongoing in the detailed design phase as required by the funding agency of the project to find out the actual ecological flow requirements of the river (Rijal, 2014). This positive trend is expected to continue in the future.

\section{Implementation Status}

Hydropower projects licensed and developed after the introduction of the Hydropower Development Policy, 2001 have started environmental flow consideration during the project development. Some of the donor funded projects also carried out the post-project assessment. The Ex-post Evaluation Report of the Kali Gandaki 'A' Hydroelectric Project (144 MW) mentions that the flow in the dry season has been observed to be reduced compared to before implementation of the project, at the diversion dam and downstream of the power plant and the population of fish has been shrinking and diversity of species have also declined as a result of shutoff of the route for route migration from the down-stream to the up-stream"(Hajime Onishi, 2010). Post project assessment indicates a positive concern for environmental flow consideration.

There have also been some studies related to the performance of the mitigation measures applied in few projects. Jha (2006) carried out a study of the fisheries in the regulated flow conditions around the Andhikhola Hydel and Rural Electrification Project (AHREP) and Sundarijal Hydropower Plants in order to examine impact of flow regulation on fisheries above and below the diversion point. The conclusion of the study is that no visible differences in terms of both the abundance and the number of species between upstream and downstream sites of the dams were found.

The legal provisions and the requirements of the funding agency have directed developers to carry out environmental flow assessment during environmental studies; however, the actual implementation status is poor. Most projects, such as the Middle Marsyangdi Hydroelectric Project (69 MW), have not provided the compensatory release as required. This has created serious impacts in the dewatered section of the river, which affects the aquatic ecosystem. The reason behind such problems is that most of the regulated rivers in Nepal have weak baseline data, poor data after hydropower plants are commissioned, and many projects also lack functional fish ladders or fish paths (KEL, 2013).

Thus, in spite of legal provisions and concerns towards environmental protection for hydropower development, a number of hydropower projects developed so far have not released minimum required environmental flow. This is due primarily to a lack of willingness on the part of developers, and poor monitoring practices by the government.

\section{Environmental Flow Practices in Other Countries}

Many developed countries have legal provisions and sophisticated and comprehensive approaches for setting flow regimes for water course management, especially in relation to hydropower. According to (Tharme, 2003), about 37 different methods have been used in Australia for EFA due to the fact that because all rivers are different, it is not possible to simply apply the same methods and guidelines to each river. In Brazil, the policies regarding the environmental issues are different at each administrative level and thus determine the approach used. According to Benetti et al. (2004), nations in the south adopt different approaches to set limits on the amount of water that can be withdrawn from rivers. For example, in Rio Grande de Sul, the policy for withdrawal is $80 \%$ of the minimum average monthly flow, and flows with a given monthly probability of exceedance using a 90\% exceedance probability.

In India, according to Anantha and Dandekar 
(2012), a recently-formed Expert Appraisal Committee (EAC) sets up a formula for each river regarding EF: "According to the current norm adopted by the EAC, the minimum continuous release from the barrage as environmental flow during the lean season will be $20 \%$ of the $90 \%$ dependable flow while during the other seasons, the release is to be higher and during monsoon season, the release is to be $30 \%$ of the $90 \%$ dependable flow in the 10-daily periods." However, there is no scientific basis for this decision.

In Norway, minimum flow releases were required only after the 1970s (Bakken et al., 2012). Today, the concept of Common Low Flow (CLF), which is normally based on $15-20$ years of data, is taken as a starting point for setting residual flows when a license is needed and used as the residual flow if a license is not needed. CLF is closely related to the $\mathrm{Q}_{95}$ low flow index. In order to account for significant seasonal variations in water flow in rivers, $Q_{95}$ is used separately for summer and winter with a higher value in summer and lower in winter; however, $Q_{95}$ provides only a constant value without considering the variation in the natural flow regime of the river. In recent years, research has been carried out in the field of environmental flows in Norway. The Building Block Methodology (BBM) has been recommended for defining environmental flow in most of the regulated rivers in Norway (Alfredsen et al., 2012). According to Halleraker et al. (2007), a suite of methodologies for EFA like habitat-hydraulic models, indicators of hydrological alteration (IHA), mesohabitat analysis, temperature simulations, and optimization of habitat improvements have been applied for optimized management of the Surna River which was designated as a national salmon water course by the Norwegian Parliament.

On the other hand, around twenty different EFMs are in use in South Africa including hydrological index, habitat simulation, holistic and combined methodologies (Tharme, 2003). BBM, DRIFT and range of methodologies for reserve determination are the most widely used. Previously, the most widely used hydrological methodology, the Tennant method, was adopted for environmental flow determination in the USA. Since the 1990s, several EFMs based on hydrological indices that address flow variability like the Range of Variability Approach (RVA) (Richter et al., 1996) has been applied in many EF studies. Habitat simulation methodologies that include IFIM and PHABSIM are also widely used EFM.

Based on the above data, the results can be summarized in Figure 2.

Figure 2 shows that different methodologies are in use for defining environmental flows in North American and European countries and that in case of Nepal is the conventional hydrological method. More studies and practices in the field of environmental flow need to be carried out in Nepal in the coming years.

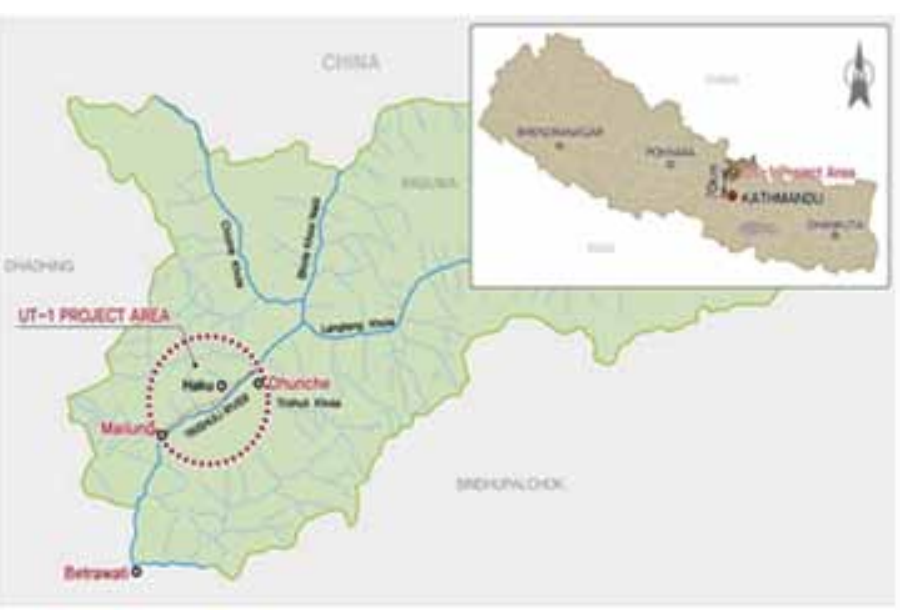

Figure 2: Relative percentage use of different types of environmental flow methodologies. For details see (Rijal, 2014)

\section{Case Study of Upper Trishuli - I Hydroelectric Project}

The Upper Trishuli-I Hydroelectric Project (UT-I HEP) is a Run-of-River (RoR) type of project currently in the detailed design phase. The proposed installed capacity of the project is 216 MW. It is located on the Trishuli River between the Haku, Dhunche and Ramche VDCs of Rasuwa district in the central development region of Nepal. The location map of the project is shown in Figure 3 .

Figure 3: Location map of the UP-I HEP (NWEDC, 2013)

\section{Current Environmental Conditions}

The Upper Trishuli-I Hydroelectric Project lies in the middle mountain zone of Nepal. Due to variations in altitude, substantial climatic differences can be observed over very short horizontal distances in the project area. Similar to other rivers, sedimentation is a common problem in the Trishuli. Landslide and mass wasting are the main sources of suspended and bed load sediment. According to (Bajracharya, 1994), the project area lies in the area of medium risk. Based on the complementary environmental and social baseline survey conducted by Nepal Environmental and Scientific Services Pvt. Ltd. (NESS, 2013), the dewatered section of the river is used for local fishing, domestic use, recreation, and irrigation.

With regards to the biological environment, the project area is rich in biodiversity with various species of flora and fauna. The Trishuli is a fast flowing river with very strong and turbulent water flows so the river and 
its tributaries are a favorable site for various fish species. The river upstream and downstream of the proposed weir site provides the best natural habitat for aquatic life. However, around the powerhouse are a, aquatic habitat may be degraded due to human interference. Table 1 below shows the aquatic habitat characterization of Trishuli River in the directly project affected area as mentioned in the EIA report. year. According to a sampling result from 2011 (NWEDC, 2013), the percentage of fish catch varies along the river. The highest percentage of fish catch has been recorded at stations III and IV, that is, above and below the weir site. The higher fish density in this area can be explained by a lower incidence of fishing, less population, and less intervention with aquatic life.

\begin{tabular}{|c|c|c|c|c|}
\hline $\begin{array}{l}\text { Station } \\
\text { No. }\end{array}$ & Name of Sampling Site & $\begin{array}{c}\text { Habitat Characterization } \\
\text { (Estimated) }\end{array}$ & Major Spawning Area & Raring Ground \\
\hline I & $\begin{array}{l}\text { At Bhote Kashi upstream of } \\
\text { the confluence between Bhote } \\
\text { Koshi and Trishuli River }\end{array}$ & $\begin{array}{l}\text { Run type of water } \\
\text { Rapid flow }(80 \%) \\
\text { Run }(10 \%) \\
\text { Deep and shallow pools ( } 5 \%) \\
\text { Riffle } \%)\end{array}$ & $\begin{array}{l}\text { Five large spawning } \\
\text { areas were observed }\end{array}$ & $\begin{array}{l}\text { Three rearing ground } \\
\text { were observed along } \\
\text { the bank of river }\end{array}$ \\
\hline II & $\begin{array}{l}\text { At Trishuli, upstream of the } \\
\text { confluence between Bhote } \\
\text { Koshi and Trishuli river }\end{array}$ & $\begin{array}{l}\text { Run type of water } \\
\text { Rapid flow }(80 \%) \\
\text { Run }(10 \%) \\
\text { Deep and shallow pools (5\%) } \\
\text { Riffle }(5 \%)\end{array}$ & $\begin{array}{l}\text { Single spawning area } \\
\text { was observed }\end{array}$ & $\begin{array}{l}\text { One rearing ground } \\
100 \text { above the } \\
\text { confluence point was } \\
\text { observed }\end{array}$ \\
\hline III & $\begin{array}{l}\text { Upstream of weir or at } \\
\text { confluence between Trishuli } \\
\text { and Bhote Koashi }\end{array}$ & $\begin{array}{l}\text { Run type of water } \\
\text { Rapid }(70 \%) \\
\text { Run }(15 \%) \\
\text { Deep and Shallow pools }(10 \%) \\
\text { Riffle }(5 \%)\end{array}$ & $\begin{array}{c}\text { Four spawning areas } \\
\text { of medium size were } \\
\text { observed }\end{array}$ & $\begin{array}{l}\text { Two rearing ground } \\
\text { under the big boulder } \\
\text { of river bank }\end{array}$ \\
\hline IV & $\begin{array}{l}\text { Downstream of weir and } \\
\text { upstream of power house area }\end{array}$ & $\begin{array}{l}\text { Run type of water } \\
\text { Rapid flow }(65 \%) \\
\text { Run }(15 \%) \\
\text { Deep and shallow pools (15\%) } \\
\text { Riffle }(5 \%)\end{array}$ & $\begin{array}{c}\text { Five small and two large } \\
\text { spawning areas were } \\
\text { observed }\end{array}$ & $\begin{array}{l}\text { Four major rear- } \\
\text { ing grounds were } \\
\text { observed }\end{array}$ \\
\hline v & $\begin{array}{l}\text { Downstream of powerhouse } \\
\text { area }\end{array}$ & $\begin{array}{l}\text { Run type of water } \\
\text { Rapid }(75 \%) \\
\text { Run }(10 \%) \\
\text { Deep and shallow pools }(10 \%) \\
\text { Riffle }(5 \%)\end{array}$ & $\begin{array}{l}\text { No remarkable spawning } \\
\text { grounds were observed }\end{array}$ & $\begin{array}{l}\text { One rearing ground } \\
\text { was observed }\end{array}$ \\
\hline
\end{tabular}

Table 1: Aquatic Habitat Characterization of Trishuli River in the Directly Project Affected Area (NWEDC, 2013)

\begin{tabular}{|l|c|c|}
\hline Months & River Discharge $\left(\mathrm{m}^{3} / \mathrm{s}\right)$ & $\begin{array}{c}\text { Environmental } \\
\text { Release }(10 \% \text { of } \\
\text { Monthly Flow) }\end{array}$ \\
\hline January & 43.5 & 4.35 \\
\hline February & 38.8 & 3.88 \\
\hline March & 38.4 & 3.84 \\
\hline April & 49.3 & 4.93 \\
\hline May & 89.2 & 8.92 \\
\hline June & 236.8 & 23.68 \\
\hline July & 500.3 & 50.03 \\
\hline August & 569.1 & 56.91 \\
\hline September & 375.7 & 37.57 \\
\hline October & 161.2 & 16.12 \\
\hline November & 79.6 & 7.96 \\
\hline December & 54.1 & 5.41 \\
\hline
\end{tabular}

Table 2: Downstream Release from Weir (Source: Feasibility Report of UT-I HEP)

There is no clear information regarding the abundance status of different fish species in the river throughout the
Due to the diversion of flow for electricity generation, approximately $11 \mathrm{~km}$ of river between the intake site and the power house site will be dewatered resulting in a reduced flow for that section. However, as required by Nepali law, at least $10 \%$ of the natural flow must be maintained. The environmental release downstream of the weir is shown in the Table 2.

\section{Environmental Flow Proposal for UT-I HEP}

UT-I HEP is funded by the International Finance Corporation (IFC). As part of its funding policies, IFC requires a cumulative impact assessment (CIA) and ecological flow assessment prior to construction.

\section{Data Collection}

For the purpose of defining the environmental flow regime for the river basin, the required hydrological, river habitat, and downstream water use data are collected. The hydrological data are provided by the Department of Hydrology and Meteorology (DHM) from the Betrawati gauging station. Data regarding the river habitat and downstream water use data along the river are taken from the existing EIA report for UT-I HEP (NWEDC, 2013) (NESS, 2014). The average, maximum, 
and minimum mean monthly flows in the Trishuli River at intake sites for 12 months for the period from 1967 to 2006 is shown in Figure 4.

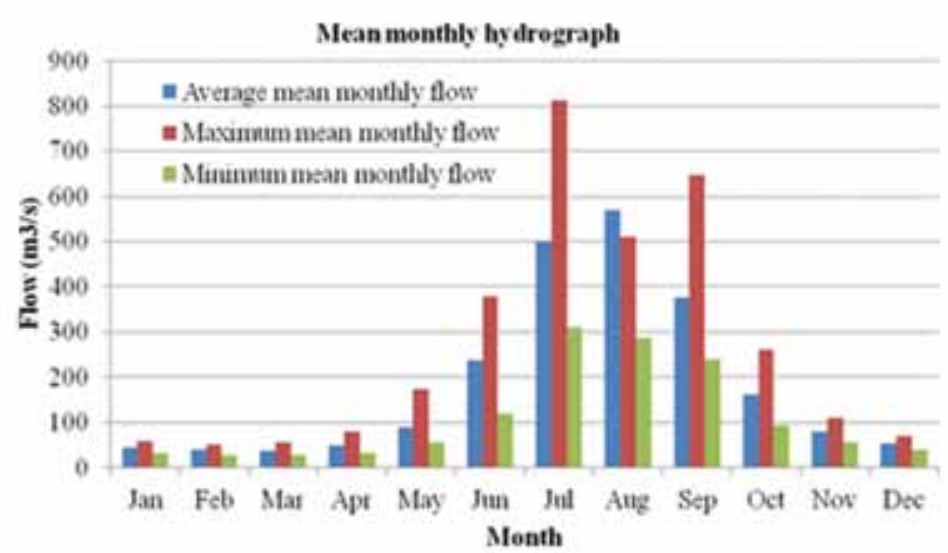

Fish species identified: $\mathrm{SN}=$ Schizothorax richardsonii; $E H=E u c h i l o g l a n i s$ hodgarti; SS=Schitura savona

\section{Identification of Key Targets}

In order to carry out the flow assessment and to set the flow regime in the dewatered river section, key ecological targets need to be defined first, since the total water requirements in the dewatered section are dependent on the flow requirements of the chosen ecological targets. In this case, flood plain vegetation, fish species and sedimentation were identified as key ecological targets for the flow regime determination. As mentioned in the EIA report, significant flow volume is not required for maintaining the flood plain vegetation and sedimentation is unlikely during the low flow periods. Thus, the environmental flow proposed in the EIA study report is sufficient to meet these requirements. Table 3 summarizes the species of fish at the various study points along the river.

The main species of snow trout found in the project area are Schizothorax richardsonii and Schizothoraichthys progastus which are mid-distance migratory fish species. These species of fish migrate upwards during March and April and during September and October which are typically important periods for spawning. Therefore, sufficient flow is required in the dewatered river stretch during these periods. The preferred habitat is gravel and boulder substrate, which is mainly found in rapid-riffle and pool habitats (NESS, 2014). These habitat conditions and their status after flow regulation need to be similar for maintaining suitable habitat for both resident and migratory fish species and must be given preference in the environmental flow regime design.

\section{Setting Environmental Flow}

The mean monthly hydrograph of the UT-I HEP project in the dewatered section of the river based on natural
Figure 5: Water uses in the dewatered river reach (NESS, 2014)

\begin{tabular}{|c|c|c|c|c|c|c|c|c|c|}
\hline \multirow{2}{*}{$\begin{array}{c}\text { Station } \\
\text { No. }\end{array}$} & \multirow{2}{*}{ Habitat type } & \multicolumn{2}{|c|}{ Aug 2013} & \multicolumn{2}{|c|}{ Sep 2013} & \multicolumn{2}{|c|}{ Oct 2013} & \multicolumn{2}{|c|}{ Nov 2013} \\
\hline & & $\mathrm{N}$ & Spp & $\mathrm{N}$ & Spp & $\mathrm{N}$ & Spp & $\mathrm{N}$ & Spp \\
\hline $\mathrm{F} 1$ & $\begin{array}{l}\text { Rapid-riffle }(30 \%), \\
\text { Riffle }(60 \%), \\
\text { Run }(10 \%) \\
\end{array}$ & 14 & SN & 24 & SN & 4 & SN & 3 & SN \\
\hline F2 & $\begin{array}{l}\text { Rapid-riffle (35\%), } \\
\text { Riffle }(45 \%), \\
\text { Run }(10 \%)\end{array}$ & 18 & SN & 41 & SN & 4 & SN & 3 & SN \\
\hline F3 & $\begin{array}{l}\text { Rapid-riffle }(30 \%), \\
\text { Riffle }(50 \%), \\
\text { Run }(20 \%)\end{array}$ & 67 & SN & 126 & $\begin{array}{c}\mathrm{SN}(124) / \\
\mathrm{EH}(2)\end{array}$ & 41 & SN & 4 & SN \\
\hline $\mathrm{F} 4$ & $\begin{array}{l}\text { Rapid-riffle }(20 \%), \\
\text { Riffle }(70 \%), \\
\text { Run }(10 \%)\end{array}$ & 78 & SN & 65 & SN & 41 & SN & 9 & SN \\
\hline F5 & $\begin{array}{l}\text { Rapid-riffle }(25 \%), \\
\text { Riffle }(65 \%), \\
\text { Run }(10 \%)\end{array}$ & 87 & $\begin{array}{l}\mathrm{SN}(86) / \\
\mathrm{EH}(1)\end{array}$ & 88 & SN & 188 & $\begin{array}{c}\mathrm{SN}(187) / \\
\mathrm{SS}(1)\end{array}$ & 47 & SN \\
\hline & Total & 264 & & 344 & & 278 & & 66 & \\
\hline
\end{tabular}

Table 3: Summary of monthly fish surveys conducted by NESS flow, proposed bypass release in the EIA report, bypass release based on HDP, 2001 and Q 95 is shown in the Figure 6:

The below hydrograph shows that the flow in the dewatered section is far below the naturally occurring low flow conditions (indicated by Q 95 value) during dry months of the year. It also shows that the regulated flow in the dewatered section of the river cannot meet the environmental water requirements of the key ecological targets for the dry months in either case of the bypass release

criterion. Therefore, a new environmental flow regime is 
proposed to meet the environmental water requirements of the key ecological targets in the low flow period in the river.

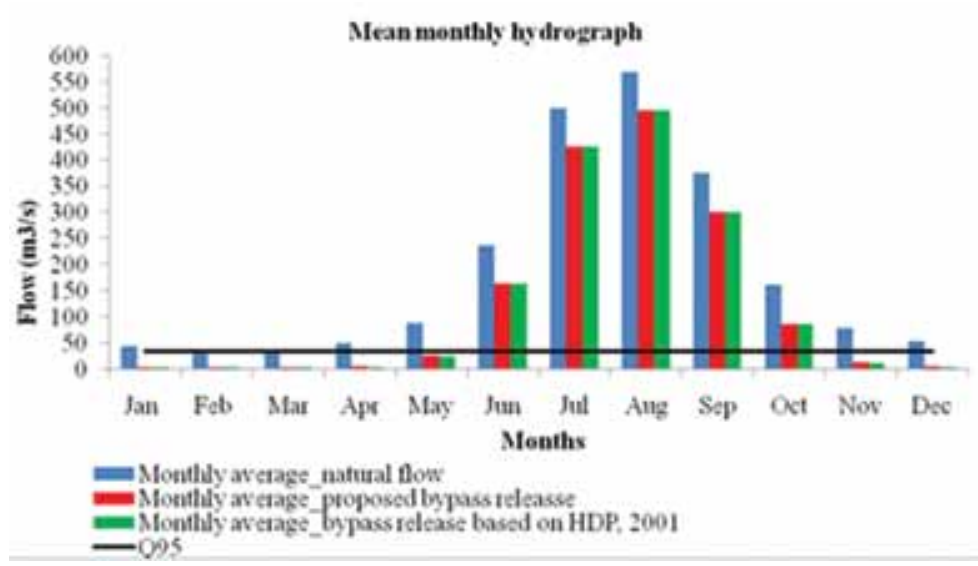

Figure 6:Mean monthly hydrograph in the dewatered river reach of UT-I HEP
Using the Tennant criteria listed above, we can establish a ranking scenario for UT-I HEP. These are shown in Table 5 and Table 6, respectively:

Assessment based on a 10\% monthly flow indicates that the ecological condition of the river in the dewatered section will be insufficient for January, February and December (Table 5).

A bypass release based on HDP, 2001 from the intake site will result in severe degradation in the ecological habitat of the river in December and January and minimum condition in February and April. In the wet seasons, the ecological habitat will remain the same for both scenarios. Thus, proposed bypass release in the EIA study seems more useful for ecological balance than the bypass release based on HDP, 2001.

The assessments of the two bypass release scenarios based on the modified Tennant

Considering the wetted area and perimeter during the low flow period, the $10 \%$ minimum flow will be insufficient to provide the minimum flow values (depth and velocity) for spawning of the snow trout. Therefore, in order to fulfill the flow requirements of the fish species in terms of magnitude and seasonal variation, a new flow regime needs to be defined for the project based on Tennant Method applied to Kali Gandaki 'A' Hydroelectric Project (KGAHEP) in Nepal (Shrestha and Chaudhary, 2013). This new regime is then compared with natural flow regimes for its suitability based on magnitude and seasonal variation.

\section{Ecological Flow Using Modified Tennant Method}

With the Tennant method, the regulated flow or the flow in the bypassed section of the river is compared with the natural flow and a rating is given based on its implications for the ecological habitat. In stream flow regimes for ecological habitats based on the Tennant Method (Tennant, 1976) applied to Kali Gandaki 'A' HEP are shown in Table 4.

\begin{tabular}{|c|c|c|}
\hline Description & $\begin{array}{c}\text { Percentage of } \\
\text { Monthly average } \\
\text { flow }\end{array}$ & Rating or score \\
\hline $\begin{array}{c}\text { Flushing or } \\
\text { maximum }\end{array}$ & 200 & 100 \\
\hline $\begin{array}{c}\text { Optimum } \\
\text { range }\end{array}$ & $60-100$ & 100 \\
\hline Outstanding & $40-59$ & 90 \\
\hline Excellent & $30-39$ & 80 \\
\hline Good & $20-29$ & 70 \\
\hline Fair & $10-19$ & $26-50$ \\
\hline Minimum & 10 & 25 \\
\hline $\begin{array}{c}\text { Severe } \\
\text { degradation }\end{array}$ & $0-9$ & $0-20$ \\
\hline
\end{tabular}

Table 4: Instream flow regimes for ecological habitat based on a modified Tennant Method (Shrestha and Chaudhary, 2013)
Method indicate the need for modifying the flow release in the dry months to improve the ecological habitat of the river. Thus, in order to improve the ecological condition from the minimum and fair condition to good condition for the low flow months, additional flow releases is required as shown in Table 7 . The proposed changes are shown in Table 8.

In order to create good riverine condition in accordance with the modified Tennant Method, a new ecological flow regime is proposed for the UT-I HEP (Table 8):

The new environmental flow regime defined with due consideration to good ecological habitat for fish is compared with the natural flow regime to evaluate its seasonal variation along with the magnitude of the proposed flow as shown in the Figure 7. The plot of natural flow versus the proposed new environmental flow depicts a certain relationship and pattern in the flow regime throughout the year. Natural variability in the flow, which is an important factor in maintaining ecosystem functions, is also depicted in the proposed environmental flow and the magnitude is expected to be sufficient for maintaining good ecological conditions for the riverine ecosystem. There will also be spill in wet periods of the year (Figure 6).

Alteration of the natural flow regime as a result of river regulation can be observed using the Indicators of Hydrologic Alteration (IHA). Two cases have been observed: one with the natural flow regime (unregulated) and the other with the new flow regime as defined for UT-I HEP (regulated). Results of the IHA statistics for some percentiles of flow is shown in Figure 8.

It is seen from Figure 8 that the variability of the $25^{\text {th }}$ percentile, median, and the $75^{\text {th }}$ percentile follows a certain trend within each flow regime. The regulated flow regime mimics the natural flow regime respectively for each of these flow values. This shows that there is no flow alteration due to regulation of flow. Therefore, the new bypass release defined for UT-I HEP is unlikely to alter the natural hydrological flow regime of the river. 


\begin{tabular}{|c|c|c|c|c|c|c|c|c|}
\hline Month & $\begin{array}{l}\text { Natural flow at } \\
\text { intake site } Q_{\text {intake }} \\
\left(\mathrm{m}^{3} / \mathrm{s}\right)\end{array}$ & $\begin{array}{c}\text { Proposed bypass } \\
\text { release } \\
Q_{\text {bypass }} \\
\left(\mathrm{m}^{3} / \mathrm{s}\right)\end{array}$ & $\begin{array}{c}\mathrm{Q}_{\text {intake }}-\mathrm{Q}_{\text {bypass }} \\
\left(\mathrm{m}^{3} / \mathrm{s}\right)\end{array}$ & $\begin{array}{l}Q_{\text {turbine }} \\
\left(\mathrm{m}^{3} / \mathrm{s}\right)\end{array}$ & $\begin{array}{l}\mathrm{Q}_{\text {spill }} \\
\left(\mathrm{m}^{\mathrm{3}} / \mathrm{s}\right)\end{array}$ & $\begin{array}{l}Q_{\text {civer }} \\
\left(\mathrm{m}^{\mathrm{j}} / \mathrm{s}\right)\end{array}$ & $\begin{array}{c}\text { Percentage of } \\
\text { natural flow }\end{array}$ & $\begin{array}{c}\text { Modified } \\
\text { tennant } \\
\text { ranking score }\end{array}$ \\
\hline Jan & 43.5 & 4.35 & 39.15 & 39.15 & 0.00 & 4.35 & 10.00 & Minimum \\
\hline Feb & 38.8 & 3.88 & 34.92 & 34.92 & 0.00 & 3.88 & 10.00 & Minimum \\
\hline Mar & 38.4 & 3.84 & 34.56 & 34.51 & 0.05 & 3.89 & 10.13 & Fair \\
\hline Apr & 49.3 & 4.93 & 44.37 & 43.59 & 0.78 & 5.75 & 11.66 & Fair \\
\hline May & 89.2 & 8.92 & 80.28 & 61.82 & 18.46 & 27.38 & 30.70 & Excellent \\
\hline Jun & 236.8 & 23.68 & 213.12 & 72.46 & 140.66 & 164.34 & 69.40 & $\begin{array}{l}\text { Optimum } \\
\text { range }\end{array}$ \\
\hline Jul & 500.3 & 50.03 & 450.27 & 73.96 & 376.31 & 426.34 & 85.22 & $\begin{array}{l}\text { Optimum } \\
\text { range }\end{array}$ \\
\hline Aug & 569.1 & 56.91 & 512.19 & 74.00 & 438.19 & 495.10 & 87.00 & $\begin{array}{l}\text { Optimum } \\
\text { range }\end{array}$ \\
\hline Sep & 375.7 & 37.57 & 338.13 & 74.00 & 264.13 & 301.70 & 80.30 & $\begin{array}{l}\text { Optimum } \\
\text { range }\end{array}$ \\
\hline Oct & 161.2 & 16.12 & 145.08 & 73.46 & 71.62 & 87.74 & 54.43 & Outstanding \\
\hline Nov & 79.6 & 7.96 & 71.64 & 65.74 & 5.90 & 13.86 & 17.41 & Fair \\
\hline Dec & 54.1 & 5.41 & 48.69 & 48.66 & 0.03 & 5.44 & 10.06 & Minimum \\
\hline
\end{tabular}

Table 5: Scenario -1 Assessment based on $10 \%$ monthly bypass release from intake

\begin{tabular}{|c|c|c|c|c|c|c|c|c|}
\hline Month & $\begin{array}{c}\text { Natural flow } \\
\text { at intake site } \\
\mathrm{Q}_{\text {intake }}\left(\mathrm{m}^{3} / \mathrm{s}\right)\end{array}$ & $\begin{array}{c}\text { Proposed by- } \\
\text { pass release } \\
\mathrm{Q}_{\text {bypass }}\left(\mathrm{m}^{3} / \mathrm{s}\right)\end{array}$ & $\begin{array}{c}\mathrm{Q}_{\text {intake }} \mathrm{Q}_{\text {bypass }} \\
\left(\mathrm{m}^{3} / \mathrm{s}\right)\end{array}$ & $\begin{array}{c}\mathrm{Q}_{\text {turbine }} \\
\left(\mathrm{m}^{3} / \mathrm{s}\right)\end{array}$ & $\begin{array}{c}\mathrm{Q}_{\text {spill }} \\
\left(\mathrm{m}^{3} / \mathrm{s}\right)\end{array}$ & $\begin{array}{c}\mathrm{Q}_{\text {river }} \\
\left(\mathrm{m}^{3} / \mathrm{s}\right)\end{array}$ & $\begin{array}{c}\text { Percentage of } \\
\text { natural flow }\end{array}$ & $\begin{array}{c}\text { Modified tenant } \\
\text { ranking score }\end{array}$ \\
\hline Jan & 43.5 & 3.84 & 39.66 & 39.66 & 0.00 & 3.84 & 8.83 & Severe degradation \\
\hline Feb & 38.8 & 3.84 & 34.96 & 34.96 & 0.00 & 3.84 & 9.90 & Minimum \\
\hline Mar & 38.4 & 3.84 & 34.56 & 34.51 & 0.05 & 3.89 & 10.13 & Fair \\
\hline Apr & 49.3 & 3.84 & 45.46 & 44.73 & 0.73 & 4.57 & 9.27 & Minimum \\
\hline May & 89.2 & 3.84 & 85.36 & 64.70 & 20.66 & 24.50 & 27.47 & Good \\
\hline Jun & 236.8 & 3.84 & 232.96 & 73.66 & 159.30 & 163.14 & 68.89 & Optimum range \\
\hline Jul & 500.3 & 3.84 & 496.46 & 74.00 & 422.46 & 426.30 & 85.21 & Optimum range \\
\hline Aug & 569.1 & 3.84 & 565.26 & 74.00 & 491.26 & 495.10 & 87.00 & Optimum range \\
\hline Sep & 375.7 & 3.84 & 371.86 & 74.00 & 297.86 & 301.70 & 80.30 & Optimum range \\
\hline Oct & 161.2 & 3.84 & 157.36 & 73.92 & 83.44 & 87.28 & 54.14 & Outstanding \\
\hline Nov & 79.6 & 3.84 & 75.76 & 68.05 & 7.71 & 11.55 & 14.51 & Fair \\
\hline Dec & 54.1 & 3.84 & 50.26 & 50.22 & 0.04 & 3.88 & 7.17 & Severe degradation \\
\hline
\end{tabular}

Table 6: Scenario-2 Assessment based on bypass release as per HDP, 2001 from intake

\begin{tabular}{|c|c|c|c|c|c|}
\hline Month & $\begin{array}{l}\text { Natural flow } \\
\text { at intake site } \\
\qquad\left(\mathrm{m}^{3} / \mathrm{s}\right)\end{array}$ & $\begin{array}{l}\text { Required bypass release for good } \\
\text { condition at } 20 \% \text { of monthly average } \\
\left(\mathrm{m}^{3} / \mathrm{s}\right)\end{array}$ & $\begin{array}{l}\text { Proposed bypass } \\
\text { release } \\
\left(\mathrm{m}^{3} / \mathrm{s}\right)\end{array}$ & $\begin{array}{l}\text { Extra release } \\
\text { required } \\
\left(\mathrm{m}^{3} / \mathrm{s}\right)\end{array}$ & Remarks \\
\hline Jan & 43.5 & 8.70 & 4.35 & 4.35 & minimum - good \\
\hline Feb & 38.8 & 7.76 & 3.88 & 3.88 & minimum - good \\
\hline Mar & 38.4 & 7.68 & 3.89 & 3.79 & fair - good \\
\hline Apr & 49.3 & 9.86 & 5.75 & 4.11 & fair - good \\
\hline Nov & 79.6 & 15.92 & 13.86 & 2.06 & fair - good \\
\hline Dec & 54.1 & 10.82 & 5.44 & 5.38 & minimum - good \\
\hline
\end{tabular}

Table 7: Extra release required for improving ecological habitat condition 


\begin{tabular}{|c|c|c|c|c|c|c|c|c|c|c|c|c|}
\hline Month & Jan & Feb & Mar & Apr & May & Jun & Jul & Aug & Sep & Oct & Nov & Dec \\
\hline $\begin{array}{c}\text { Bypass } \\
\text { release }\end{array}$ & 8.70 & 7.76 & 7.68 & 9.86 & 8.92 & 23.68 & 50.03 & 56.91 & 37.57 & 16.12 & 15.92 & 10.82 \\
\hline
\end{tabular}

Table 8: Ecological flow regime for UT-I HEP

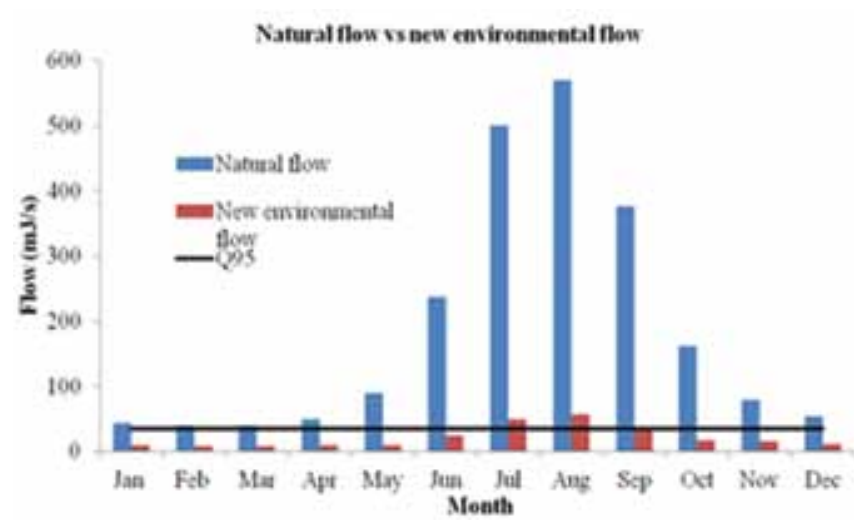

Figure 7: Comparison between natural flow and environmental flow regime

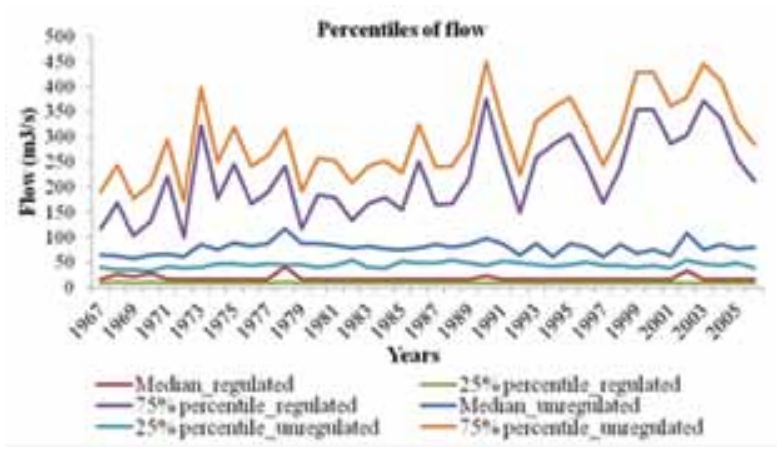

Figure $8: 25^{\text {th }}$ percentile, median and $75^{\text {th }}$ percentile for regulated and unregulated flow

Similarly, the plots of minimum and maximum flows in March and April which are the most important periods for snow trout spawning have been made for both cases as shown in Figure 9 and Figure 10. In case of the natural flow regime, minimum monthly flows for both months should be above $30 \mathrm{~m}^{3} / \mathrm{s}$ and there is some distinct variability in the minimum flow values along the time series. On the other hand, in the regulated flow regime, there is not distinct variability in the minimum flow values for both of these months along the time series.

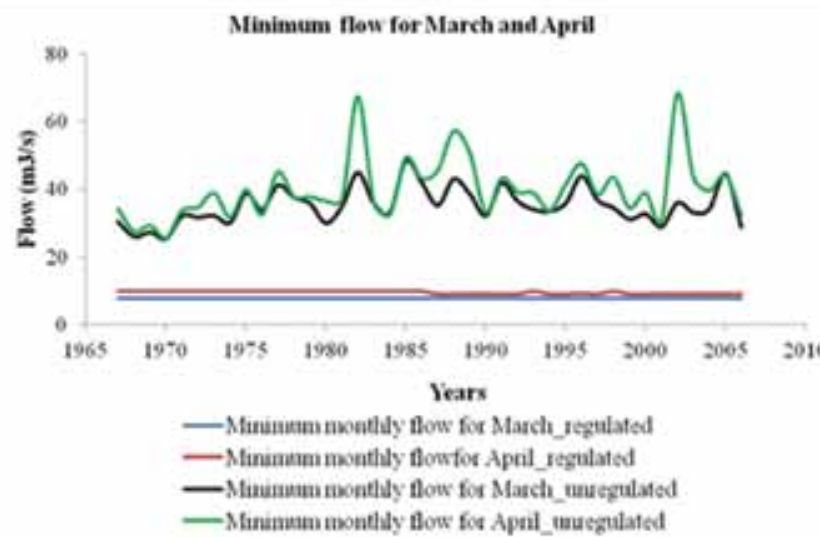

Figure 9: Minimum monthly flow in March and April for regu.lated and unregulated case

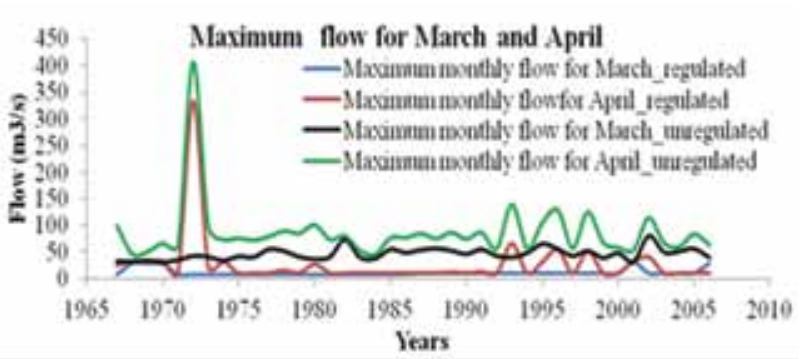

Figure 10: Maximum monthly flow in March and April for regulated and unregulated case

Likewise, the plots of maximum monthly flow for both regulated and unregulated cases indicate that there is great variability in the maximum flow values in April in both cases. But in March, there is not significant variation in either case. However, the regulated flow in these months follows the trend of unregulated flow in the corresponding months indicating that the proposed flow regime should function ecologically.

\section{nMAG Simulation}

The system defined for UT-I HEP was simulated using the nMAG hydropower model. The components of the nMAG are illustrated in Figure 11.

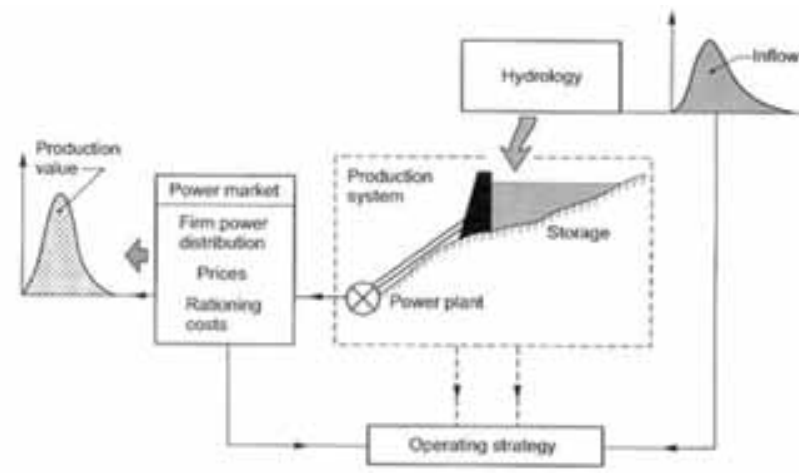

Figure 11: Main components in a hydropower simulation model (Killingtveit and Sælthun, 1995)

In this case, a model of the UT-I HEP project has been depicted in nMAG and the system is simulated for various bypass release scenarios to evaluate the effect of environmental flows on production value. The simulation was run using firm energy level of 1,557 GWh. The difference in the production values for different bypass release scenarios is shown in the Table 9.

The loss in the production value is greater for the new flow regime as defined for UT-I HEP. The firm energy level is kept high so that additional energy or the dump energy produced is comparatively small with demand coverage lower than the firm energy level. Hence, the effect of rationing can be visualized for dry months with greater effects for higher bypass releases and vice-versa. 


\begin{tabular}{|l|c|c|c|c|}
\hline Scenarios & $\begin{array}{c}\text { Firm power } \\
\text { value (mill. } \\
\text { US\$) }\end{array}$ & $\begin{array}{c}\text { Operation } \\
\text { costs } \\
\text { (mill. } \\
\text { US\$) }\end{array}$ & $\begin{array}{c}\text { Net } \\
\text { Benefit } \\
\text { (mill. US } \\
\mathbf{\$} \text { ) }\end{array}$ & $\begin{array}{c}\text { Loss } \\
\text { (mill. } \\
\text { US } \\
\mathbf{\$} \text { ) }\end{array}$ \\
\hline $\begin{array}{l}\text { No bypass } \\
\text { release }\end{array}$ & 79.41 & 2.79 & 76.62 & \\
\hline $\begin{array}{l}\text { Bypass } \\
\text { release } \\
\text { based on } \\
\text { new flow } \\
\text { regime }\end{array}$ & 79.41 & 10.12 & 69.288 & 7.34 \\
\hline $\begin{array}{l}\text { Proposed } \\
\text { bypass } \\
\text { release }\end{array}$ & 79.41 & 6.79 & 72.62 & 4.00 \\
\hline $\begin{array}{l}\text { Bypass } \\
\text { release } \\
\text { based on } \\
\text { HDP, 2001 }\end{array}$ & 79.41 & 5.56 & 73.84 & 2.77 \\
\hline
\end{tabular}

Table 9: Comparison of economic results with firm energy level of 1557 GWh

The effects of different bypass release scenarios on power production are shown in Figure 12 below.

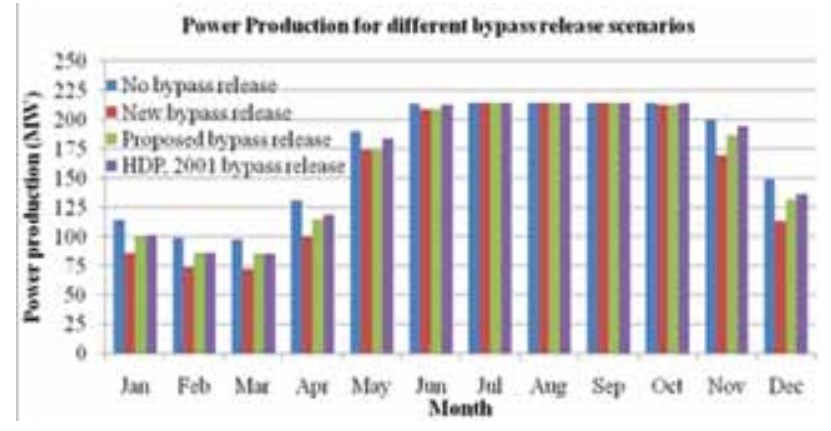

Figure 12: Power production for different bypass release scenarios

From Figure 12, we can see that bypass release based on the new flow regime defined for UT-I HEP will reduce the power production especially during the low flow periods of the year. Reduction in power production is prominent for February and March as compared to the other months. However, for the wet months of the year, there is no effect of the new flow regime on power production as compared to the other scenarios. This is due to the fact that the same bypass release is allocated for wet seasons in the new flow regime as proposed in the EIA study.

\section{Comparison between the Current Approaches and Upper Trishuli- I HEP}

The environmental flow regime as defined for the UT-I HEP shows a seasonal variation in the flow allocation that mimics the natural flow regime in the dewatered section of the river. The flow allocation has been made such that the bypass release during the dry months is sufficient enough to maintain good ecological condition of the river although they are lower than the natural flow in the river as shown in Figure 13. The flow regime has been decided based on the river habitat data collected during the ongoing field studies and the hydrological data available in feasibility reports. Whereas, the existing environmental flow regime is based on the $10 \%$ of the minimum monthly average flow, bypass release for the dry months starting from November to April is far below the natural flow and naturally occurring low flow indicated by $\mathrm{Q}_{95}$. This bypass release is augmented by flood spill during the wet months so the regime looks positive for the wet months of the year.

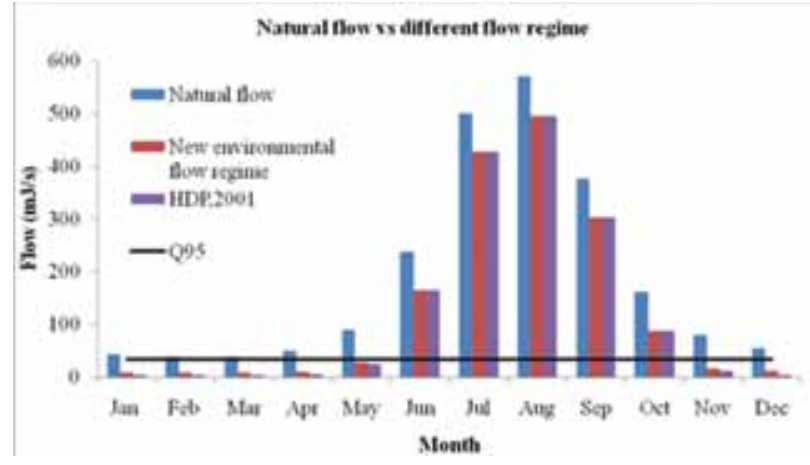

Figure 13: Different environmental flow regime for UT-I HEP

The comparison between the environmental flow regime defined for UT-I HEP and the flow regime defined based on the HDP, 2001 is as shown in Figure 14.

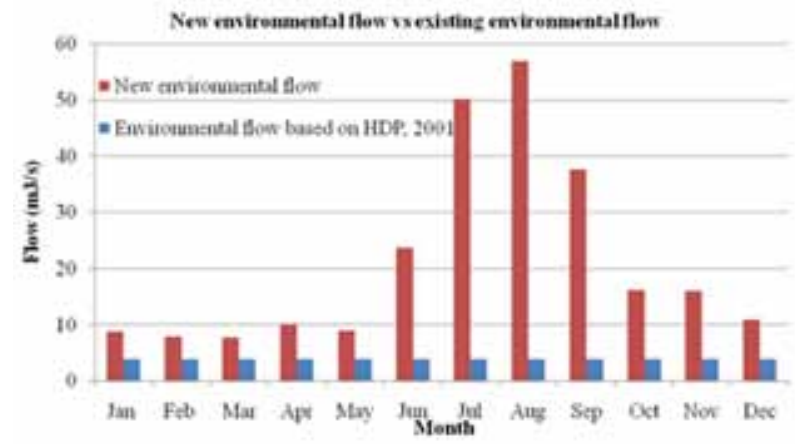

Figure 14: Plots of new environmental flow and environmental flow based on HDP, 2001

In simpler terms, Figure 14 shows that the flow regime based on the HDP, 2001 fails to perform its required ecological function during the low flow period and that riverine ecology could be severely degraded during these periods. Since, the adjusted flow regime considers key ecological targets and downstream water uses, it can fulfill ecosystem functions to a good extent using the rating derived from the modified Tennant method.

\section{Conclusion}

The existing minimum flow practices currently used do not properly consider project-specific scenarios and field measurements for downstream flow allocation. Environmental release of water based on a fixed percentage of the minimum monthly average flow does not include habitat condition requirements for key target species of the river reach considered. Therefore, the lack of detailed field studies and proper assessments has led to situations with inadequate information on how the hydraulic variables of the river like depth, velocity, wetted perimeter, and water surface elevation will change as the flow regime changes. This indicates that the basis of selection of minimum flow release based on the existing 
practices in Nepal bears no scientific approach and is merely a statistical representation of natural flow regime (Tharme, 2003). The decrease in the value of power production during the dry months is due to the fact that greater flow is released for ecological functioning when the natural flow in the river is low.

For UT-I HEP, we have determined new flow regimes defined for the project that have been based on detailed field studies. The effect of flow changes in river morphology, sedimentation process, water quality and temperature changes will be of great importance in habitat change studies that has been addressed in deciding the flow regime for UT-I HEP case. It has been carefully considered during the flow regime determination for UT-I HEP.

Thus, it is evident that there have been a lot of changes in the approaches and methodologies in deciding environmental flow regime between the past methods and the present approach used in the case of the UT-I HEP. Instead of allocating a fixed statistical value based on the long term hydrological series for the project, many field measurements and other assessments will be needed for deciding the actual habitat conditions of the rivers where hydropower projects are being considered. This holistic approach to understanding flow regimes helps to understand the hydrological conditions (flow variationsdaily, monthly and yearly) in relation to human water uses needs and the thriving ecology of the targeted fauna and flora while applying the environmental flow methodologies (KEL, 2013).

\section{Acknowledgements}

The writers would like to thank Mr. Salil Devkota, Managing Director of NESS Pvt. Ltd., for his kind cooperation and assistance in providing the field measurements and other relevant data related to the UT-I HEP.

Narayanhari Rijal holds Master's degree in Hydropower Development from Norwegian University of Science and Technology (NTNU), Norway. He is currently working in Paragon Engineering Consultancy and Research Centre Pvt. Ltd. as Chairperson and is involved in management of various infrastructure projects undertaken by the firm.

Corresponding address: narayanin2004@gmail.com

Knut Alfredsen a PhD in Hydraulic Engineering from NTNU, is a Professor at the Department of Hydraulic and Environmental Engineering, NTNU, Norway. He has been working at the department since 2002. His areas of research are hydrological modeling, cold climate hydrology and environmental impacts of hydropower. He has published 30 papers in international peer-reviewed journals.

\section{Email address: knut.alfredsen@ntnu.no}

\section{References}

Alfredsen, K., Harby, A., Linnansaari, T. \& Ugedal Gedal, O. 2012. Development of an Inflow-Controlled Environmental Flow Regime for a Norwegian River. River Research and Applications, 28, 731-739.
Anantha, L. \& Dandekar, P. 2012. A Primer on Environmental flows.

Bajracharya, R. 1994. Preliminary seismic risk evaluation of Nepal. Individual studies by participants to the International Institute of Seismology and Earthquake Engineering, 30, 113-127.

Bakken, T. H., Zinke, P., Melcher, A. \& Sundt, H. 2012. Setting environmental flows in regulated rivers.

Benetti, A., Lanna, A. \& Cobalchini, M. 2004. Current practices for establishing environmental flows in Brazil. River research and applications, 20, 427-444.

Bovee, K. D., Lamb, B. L., Bartholow, J. M., Stalnaker, C. B. \& Taylor, J. 1998. Stream habitat analysis using the instream flow incremental methodology. DTIC Document.

Dunbar, M., Acreman, M. \& Kirk, S. 2004. Environmental flow setting in England and Wales: strategies for managing abstraction in catchments. Water and Environment Journal, 18, 5-10.

Hajime Onishi, M. U. R. C. C., LTD 2010. Ex-post Evaluation of Japanese ODA Loan Project 'Kali Gandaki 'A' Hydroelectric Project.

Halleraker, J., Sundt, H., Alfredsen, K. \& Dangelmaier, G. 2007. Application of multiscale environmental flow methodologies as tools for optimized management of a Norwegian regulated national salmon watercourse. River Research and Applications, 23, 493-510.

Jha, B. R. 2006. Fish ecological studies and its application in assessing ecological integrity of rivers in Nepal. Department of Environmental Science and Engineering, Kathmandu University.

KEL 2013. Environmental Imapct Assessment Study of Kabeli-A Hydroelectric Project, Kathmandu, Nepal, Kabeli Energy Limited

Killingtveit, A. \& Saelthun, N. R. 1995. Hydrology, Norwegian Institute of Technology Division of Hydraulic Engineering.

NESS 2013. Complementary environmental and social baseline survey, Nepal Environmental and Scientific Services P. Ltd. .

NESS 2014. Draft report on Cumulative Impact Assessment of UT-I HEP, Nepal Environmental and Scientific Services P. Ltd. .

NWEDC 2013. Environmental Impact Assessment (EIA) Study of UT-I HEP, Nepal Water and Energy Development Company

Richter, B. D., Baumgartner, J. V., Powell, J. \& Braun, D. P. 1996. A method for assessing hydrologic alteration within ecosystems. Conservation biology, 10, 11631174.

Shrestha, J. \& Chaudhary, R. 2013. Ecological flow assessment of Kabeli River. update.

Tennant, D. L. 1976. Instream flow regimens for fish, wildlife, recreation and related environmental resources. Fisheries, 1, 6-10.

Tharme, R. E. 2003. A global perspective on environmental flow assessment: emerging trends in the development and application of environmental flow methodologies for rivers. River research and applications, 19, 397-441. 